\title{
REKASI PASAR TERHADAP KARAKTERISTIK PERUSAHAAN DAN KANTOR AKUNTAN PUBLIK
}

\section{YOHANES FERNANDES dan YULIUS KURNIA SUSANTO}

\author{
STIE Trisakti \\ yulius@stietrisakti.ac.id
}

\begin{abstract}
The purpose of this study is to investigation over the influence of profitability, firm size, registered public accountant switch, auditor working period, audit opinion, reputation of registered public accountant against cumulative abnormal return. This study uses 65 samples of public manufacturing companies listed in Indonesia Stock Exchange from 2007 to 2010 which acquired using sampling purposive method, and obtained from annual report and audit report for each company. This study also use multiple regression analysis. The result of this research obtained that profitaibility and reputation of registered public accountant have a positive in influence cumulative abnormal return. While firm size, registered public accountant switch, auditor working period, and audit opinion have no impact on cumulative abnormal return.
\end{abstract}

Keywords: Profitability, company's size, registered public accountant, audit opinion and cumulative abnormal return.

\section{PENDAHULUAN}

Fenomena pergantian auditor atau kantor akuntan publik (KAP) menarik untuk dikaji, hal ini dikarenakan banyak faktor yang dapat mempengaruhi pergantian auditor atau KAP yang dilakukan oleh perusahaan. Faktor-faktor tersebut dapat dipengaruhi oleh faktor eksternal maupun faktor internal perusahaan. Sebelum runtuhnya Arthur Anderson sebagai salah satu KAP besar yang masuk dalam jajaran empat KAP terbesar di dunia (the Big Four) karena keterlibatannya dalam manipulasi keuangan yang dilakukan oleh 
perusahaan minyak besar di Amerika, Enron, sedikit sekali perusahaan yang melakukan pergantian auditor atau KAP mereka.

Hal tersebut disebabkan karena perusahaan telah merasa "nyaman" dengan hubungan yang terjalin selama ini antara KAP dengan pihak manajemen perusahaan. Namun dengan dikeluarkannya Keputusan Menteri Keuangan Nomor 423/KMK.06/2002 dan KMK Nomor 359/KMK.06/2003 yang telah direvisi dengan Peraturan Menteri Keuangan Nomor: 17/PMK.01/ 2008 tentang jasa akuntan publik mengenai pembatasan masa pemberian jasa audit oleh KAP selama maksimal 6 tahun berturut-turut dan auditor selama maksimal 3 tahun berturut-turut, menyebabkan perusahaan mau tidak mau memiliki keharusan untuk melakukan pergantian auditor dan KAP mereka setelah jangka waktu tertentu sesuai dengan peraturan pemerintah.

Selain adanya faktor eksternal yang dapat mempengaruhi perusahaan untuk berganti KAP, terdapat pula faktor-faktor internal perusahaan yang dapat mempengaruhi keputusan perusahaan untuk berganti KAP. Beberapa penelitian terdahulu telah mencoba mengangkat isu ini, penelitian tersebut antara lain dilakukan oleh Chow dan Rice (1982) dalam Diaz (2009), yang mencoba melihat pengaruh opini "qualified" yang dikeluarkan oleh auditor terhadap pergantian auditor. Dari hasil pengujiannya ini diperoleh hasil bahwa banyak perusahaan yang melakukan pergantian auditor lebih disebabkan karena menerima opini "qualified" dari auditor sebelumnya. Kemudian terdapat pula penelitian dari Krishnan (1994) dalam Diaz (2009), yang meneliti mengenai pergantian auditor dan konservatisme, hasil penelitiannya menunjukkan bahwa kemungkinan pergantian auditor lebih disebabkan bukan karena opini "qualified" semata tetapi juga karena penilaian konservatif yang diberikan oleh auditor.

Di Indonesia, penelitian mengenai faktor-faktor internal perusahaan yang mempengaruhi pergantian auditor ataupun KAP juga dilakukan oleh Damayanti (2007) dalam Diaz (2009) yang mencoba meneliti mengenai faktorfaktor yang mempengaruhi perusahaan perpindah KAP dengan menggunakan variabel independen seperti pergantian manajemen, opini akuntan, fee audit, kesulitan keuangan perusahaan, ukuran KAP, dan persentase perubahan ROA. Selain itu terdapat juga penelitian dari Kawijaya dan Juniarti (2002) yang meneliti mengenai faktor-faktor yang mempengaruhi perpindahan auditor (auditor switch) pada perusahaan-perusahaan di Surabaya dan Sidoarjo dengan menggunakan variabel seperti qualified audit opinion, merjer, management changes, dan ekspansi dalam memprediksi perpindahan auditor.

Penelitian mengenai fenomena pergantian KAP ini menjadi semakin menarik untuk dikaji ketika dihubungkan dengan perilaku investor, terutama bagaimana investor menyikapi pergantian KAP yang dilakukan oleh perusa- 
haan. Dimana selama ini investor seringkali bereaksi terhadap informasi dan perubahan kebijakan yang dilakukan perusahaan. Scott (2003) menyatakan bahwa informasi akuntansi berguna bagi investor untuk membantu mereka dalam mengestimasi nilai yang diharapkan dan risiko dari return sekuritas. Investor melakukan analisis, karena mereka tentu tidak menginginkan risiko yang tinggi yang nantinya dapat menyebabkan modal yang telah mereka keluarkan tidak dapat kembali karena investasinya tidak berkembang sebagaimana yang diharapkan.

Penelitian ini memiliki berbedaan dari penelitian yang mengangkat isu pergantian KAP yang hanya melihat dari sudut pandang faktor-faktor yang mempengaruhi pergantian KAP semata. Penelitian ini mencoba melihat pengaruh pergantian KAP ini dari kacamata investor, yaitu dengan melihat perilaku investor yang tercermin dari reaksi pasar yang ditimbulkan atas pergantian KAP yang diumumkan oleh perusahaan, hal ini dapat terlihat dari reaksi pasar yang digambarkan dalam bentuk cumulative abnormal return.Tujuan penelitian adalah untuk mendapatkan bukti empiris bahwa ada pengaruh profitabilitas, ukuran perusahaan, pergantian Kantor Akuntan Publik, lama tugas pengauditan, opini audit dan reputasi Kantor Akuntan Publik terhadap cumulative abnormal return.

\section{RERANGKA TEORITIS DAN PENGEMBANGAN HIPOTESIS}

\section{Signaling Theory}

Teori sinyal selalu berhubungan dengan pengungkapan informasi yang dilakukan oleh perusahaan kepada pihak di luar perusahaan. Sinyal yang diberikan ini dapat berupa laporan yang diwajibkan maupun pengumumanpengumuman yang berhubungan dengan tindakan yang diambil oleh perusahaan. Dalam beberapa penelitian, pengujian teori sinyal bertujuan untuk melihat sejauhmana kandungan informasi yang dimiliki oleh suatu pengumuman yang diungkapkan oleh perusahaan. Hartono (2008) menjelaskan beberapa pengumuman yang biasanya digunakan dalam pengujian teori ini antara lain adalah pengumuman yang berhubungan dengan laba, pengumuman deviden, pengumuman megenai pendanaan dan investasi, pengumuman yang berhubungan dengan kebijakan pemerintah, pengumuman mengenai ketenagakerjaan, pengumuman yang berhubungan dengan hukum dan kegiatan produksi, pemasaran serta penjualan, pengumuman dari manajemen dan direksi hingga pengumuman-pengumuman yang berhubungan dengan industri sekuritas. 


\section{Pengembangan Hipotesis}

Penelitian yang dilakukan oleh Ulupui (2005) membuktikan bahwa Return on Asset berpengaruh terhadap Abnormal Return. Penelitian ini juga sesuai dengan Syauta dan Widjaja (2009), tidak terjadi hubungan antara Return on Asset dengan Average Abnormal Return. Penelitian yang dilakukan oleh Diaz (2009) membuktikan bahwa ukaran perusahaan tidak berpengaruh terhadap Cumulative Abnormal Return. Berbeda dengan penelitian yang dilakukan oleh Maryanti (2009 membuktikan bahwa ukaran perusahaan berpengaruh terhadap Abnormal Return. Penelitian yang dilakukan oleh Mulyani et al. (2009) membuktikan bahwa ukaran perusahaan berpengaruh terhadap Cummulative Abnormal Return. Penelitian yang dilakukan oleh Djam'an et al. (2010) membuktikan bahwa ukuran perusahaan berpengaruh terhadap Abnormal Return.

Penelitian yang dilakukan oleh Diaz (2009) membuktikan bahwa Pergantian Kantor Akuntan publik berpengaruh terhadap Cumulative Abnormal Return. Penelitian yang dilakukan oleh Diaz (2009) membuktikan bahwa lama penugasan Kantor Akuntan Publik tidak berpengaruh terhadap Cumulative Abnormal Return. Lama penugasan Auditor yang diteliti pada penelitian ini dipakai untuk menggantikan lama penugasan Kantor Akuntan Publik.

Berdasarkan penelitian yang dilakukan oleh Wicaksono dan Raharja (2012) bahwa tidak terjadi hubungan antara opini audit baik wajar tanpa pengecualian maupun wajar tanpa pengecualian dengan paragraf penjelas dengan variabel dependen Average Abnormal Return. Penelitian ini juga sesuai dengan Meiden (2008), tidak terjadi hubungan antara opini audit baik wajar tanpa pengecualian maupun wajar tanpa pengecualian dengan paragrap penjelas dengan Average Abnormal Return. Penelitian yang dilakukan oleh Riyatno (2007) bahwa terjadi hubungan antara Reputasi Kantor Akuntan Publik atau yang disebutkan sebagai ukuran Kantor Akuntan Publik dengan Earning Respons coefficient yang dihitung menggunakan Cumulative Abnormal Return. Hipotesis penelitian yang diajukan dalam penelitian ini adalah sebagai berikut:

$\mathrm{H}_{1}$ Profitabilitas berpengaruh terhadap cumulative abnormal return.

$\mathrm{H}_{2} \quad$ Ukuran perusahaan berpengaruh terhadap cumulative abnormal return.

$\mathrm{H}_{3}$ Pergantian Kantor Akuntan Publik berpengaruh terhadap cumulative abnormal return.

$\mathrm{H}_{4} \quad$ Lama penugasan Auditor berpengaruh terhadap cumulative abnormal return.

$\mathrm{H}_{5} \quad$ Opini Audit berpengaruh terhadap cumulative abnormal return.

$\mathrm{H}_{6} \quad$ Reputasi Kantor Akuntan Publik berpengaruh terhadap cumulative abnormal return. 
Model penelitian yang akan diuji dalam penelitian ini adalah:

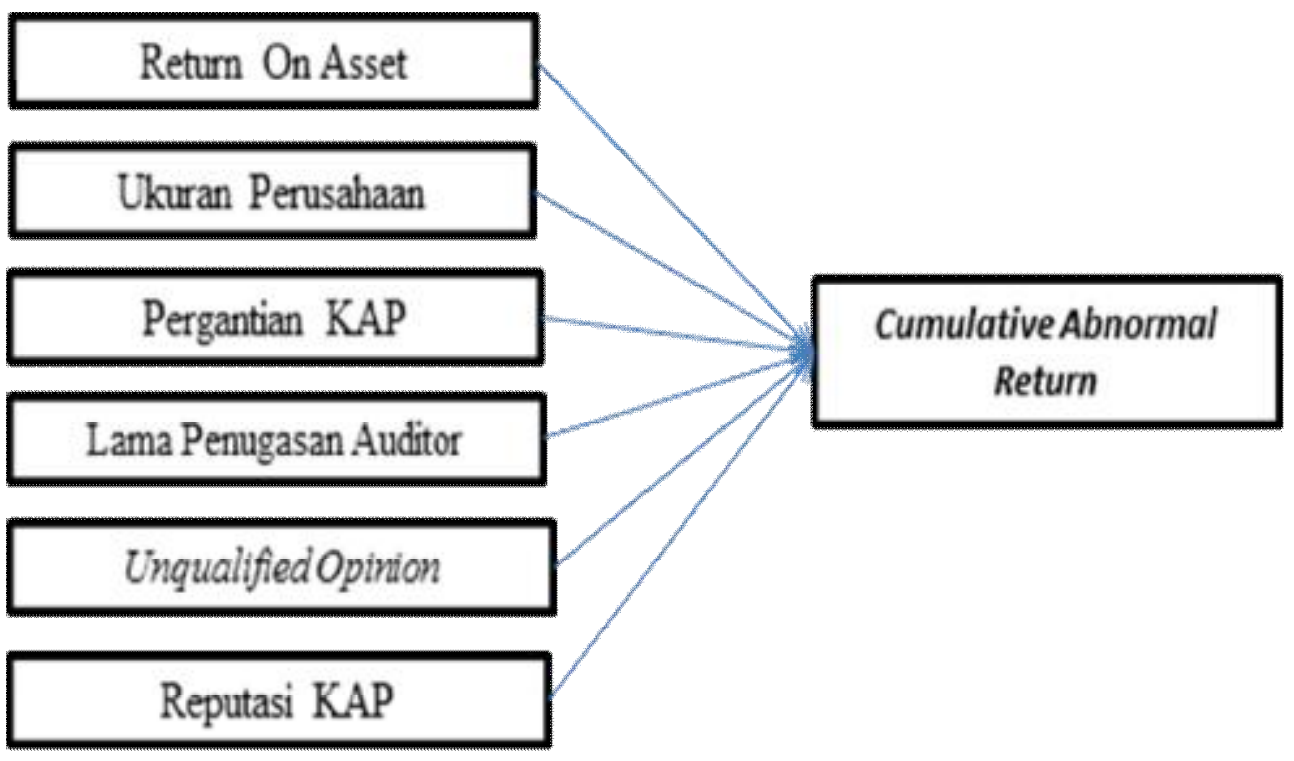

Gambar 1 Model Penelitian

\section{METODA PENELITIAN}

\section{Pemilihan Sampel dan Pengumpulan Data}

Dalam penelitian ini populasi data yang digunakan adalah seluruh perusahaan manufaktur yang terdaftar di Bursa Efek Indonesia pada tahun 2006 sampai dengan 2010. Pemilihan sektor manufaktur ini bertujuan untuk menghindari adanya industrial effect yaitu risiko industri yang berbeda antara suatu sektor industri yang satu dengan yang lainnya. Selain itu industri manufaktur memiliki jumlah perusahaan terdaftar paling banyak dibandingkan dengan industri lain. Sampel yang digunakan penelitian ini adalah sebanyak 65 perusahaan manufaktur yang terdaftar di Bursa Efek Indonesia. Sampel tersebut dipilih berdasarkan kriteria pemilihan sampel yang telah ditentukan sebagai berikut: 


\section{Tabel 1 Prosedur Pemilihan Sampel}

\begin{tabular}{|c|c|c|}
\hline No & Keterangan & Jumlah \\
\hline 1. & $\begin{array}{l}\text { Perusahaan manufaktur yang terdaftar di BEI secara } \\
\text { konsisten dari tahun 2006-2010 dan memiliki akhir tahun } \\
\text { buku } 31 \text { Desember }\end{array}$ & 125 \\
\hline 2. & $\begin{array}{l}\text { Perusahaan manufaktur mengalami kerugian selama } \\
\text { periode } 2007-2010\end{array}$ & $(47)$ \\
\hline 3. & $\begin{array}{l}\text { Perusahaan manufaktur yang menyajikan laporan } \\
\text { keuangan bukan dalam mata uang Rupiah (Rp) }\end{array}$ & (1) \\
\hline 4. & $\begin{array}{l}\text { Data laporan keuangan tidak tersedia secara lengkap } \\
\text { selama tahun 2006-2010 }\end{array}$ & $(12)$ \\
\hline 5. & Total perusahaan yang digunakan dalam penelitian & 65 \\
\hline 6. & Total data yang dijadikan sebagai sampel dalam penelitian & 195 \\
\hline 7. & Data yang dikeluarkan dari sampel akibat uji outlier & (15) \\
\hline 8. & Total data yang dijadikan sebagai sampel dalam penelitian & 180 \\
\hline
\end{tabular}

Sumber: Pengolahan Data

\section{Definisi Operasional Variabel dan Pengukurannya}

Profitabilitas merupakan rasio perbandingan antara laba bersih dengan aset yang secara tidak langsung juga mengukur kemampuan perusahaan mengelola aset untuk menghasilkan laba bersih (Gitman 2006). Semakin besar rasio ini semakin baik, karena hal ini berarti bahwa semakin cepatnya perputaran aktiva dan perolehan laba perusahaan (Susanto 2009). Variabel ini diberi simbol ROA. Rasio ini diukur dengan rumus sebagai berikut:

$$
\begin{array}{ll}
\text { Return On Asset } \quad=\frac{\text { Net Income }}{\text { Total Assets }} \\
\hline
\end{array}
$$

Ukuran perusahaan merupakan total nilai dari kekayaan yang dimiliki oleh perusahaan. Variabel ini diukur dengan menggunakan natural logarithma dari total assets di tahun sebelum pergantian KAP sebagai sebuah proksi untuk ukuran perusahaan (Diaz 2009).

Pergantian Kantor Akuntan Publik yang dimaksudkan dalam penelitian ini adalah jika perusahaan mengunakan Kantor Akuntan Publik (KAP) yang berbeda tiap tahunnya (bukan bersifat mandatory). Jika terjadi pergan- 
tian salah satu partner atau lebih, peneliti maksudkan sebagai rotasi partner dan bukan pergantian KAP (Sinarwati 2010). Pengukuran atas pergantian kantor akuntan publik ini menggunakan skala nominal dengan menggunakan variabel dummy. Nilai 1 jika perusahaan melakukan pergantian dari Kantor Akuntan Publik (KAP) dan 0 untuk tidak melakukan pergantian.

Berdasarkan Keputusan Menteri Keuangan Nomor 423/KMK.06/2002 dan KMK Nomor 359/KMK.06/2003 yang telah direvisi dengan Peraturan Menteri Keuangan Nomor: 17/PMK.01/2008 tentang jasa akuntan publik mengenai pembatasan masa pemberian jasa audit oleh KAP selama maksimal 6 tahun berturut-turut dan auditor selama maksimal 3 tahun berturut-turut. Penelitian ini memakai waktu pengamatan 3 tahun ke belakang secara berturut-turut untuk auditor yang menandatangani laporan audit. Pengukuran variabel lama penugasan auditor menggunakan variabel dummy, nilai 1 untuk perusahaan yang telah melakukan pergantian auditor selama periode 3 tahun berturut-turut, dan 0 untuk perusahaan yang tidak melakukan pergantian.

Laporan Keuangan yang telah dinyatakan sesuai dengan standar akuntansi yang berlaku umum dan dinilai wajar dari salah saji yang material maka akan diberikan opini wajar tanpa pengecualian (unqualified opinion) oleh auditor. Pengukuran variabel opini audit dengan menggunakan variabel dummy, nilai 1 untuk perusahaan dengan opini wajar tanpa pengecualian dan 0 untuk selain itu. Reputasi Kantor Akuntan Publik (KAP) dapat diketahui berdasarkan peringkat sebuah KAP dalam suatu negara. Pengukuran variabel ini menggunakan variabel dummy, nilai 1 jika perusahaan diaudit oleh KAP Big Four dan 0 untuk selain itu.

Reaksi pasar yang digambarkan dengan Cumulative Abnormal Return (CAR). Hipotesis yang ada diuji dengan menggunakan analisis regresi, seperti yang dilakukan dalam penelitian Knechel et.al. (2007) dalam Diaz (2009). Berikut adalah langkah-langkah menghitung Cumulative Abnormal Return (CAR) merupakan proksi dari harga saham atau reaksi pasar:

$$
\mathrm{R}_{\mathrm{i}}=\frac{\mathrm{R}_{\mathrm{t}}-\mathrm{R}_{\mathrm{t}-1}}{\mathrm{R}_{\mathrm{t}-1}}
$$

$$
\mathrm{R}_{\mathrm{m}}=\frac{\mathrm{IHSG}_{\mathrm{t}}-\mathrm{IHSG}_{\mathrm{t}-1}}{\mathrm{IHSG}_{\mathrm{t}-1}}
$$


$C A R=\sum_{i=15}^{n} R i-R m$

$\mathrm{R}_{\mathrm{i}} \quad$ Acctual return saham perusahaan $\mathrm{i}$ hari ke $\mathrm{t}$

$\mathrm{R}_{\mathrm{t}} \quad$ Harga saham perusahaan $\mathrm{i}$ hari ke $\mathrm{t}$

$\mathrm{R}_{\mathrm{t}-1} \quad$ Harga saham perusahaan i hari ke $\mathrm{t}-1$

$\mathrm{R}_{\mathrm{m}} \quad$ Acctual return pasar hari ke $\mathrm{t}$

IHSG $_{\mathrm{t}} \quad$ Nilai Indeks Harga Saham Gabungan (IHSG) hari ke t

IHSG $_{\mathrm{t}-1}$ Nilai Indeks Harga Saham Gabungan (IHSG) hari ke t-1

CAR Cumulative Abnormal Return

Penelitian ini menggunakan model regresi berganda sebagai berikut:

CARit $=a+b_{1} R O A+b_{2} S I Z E+b_{3} K A P+b_{4} A D T O R+b_{5} \mathrm{OPINI}+b_{6} R E P \_K A P+$ eit

Keterangan:

CARit Return tidak normal kumulatif (cumulative abnormal return) selama 7 (tujuh) hari untuk perusahaan i, dalam waktu t-7 sampai $\mathrm{t}+7$ dimana $\mathrm{t}$ adalah tanggal pengumuman pergantian akuntan publik. Nilai return ekspektasi untuk mendapatkan nilai CAR dihitung dengan menggunakan market model.

ROA Returrn on Asset memakai rumus (Net Income/Net Asset)

Size Natural Log dari total asset di tahun sebelum pergantian KAP.

KAP Variabel dummy,1 jika perusahaan melakukan pergantian KAP, dan 0 bila sebaliknya.

ADTOR Variabel dummy,1 jika melakukan pergantian auditor selama 3 tahun berturut-turut sebelumnya , dan 0 bila bila tidak.

OPINION Variabel dummy,1 jika perusahaan dengan opini wajar tanpa pengecualian dan 0 untuk selain itu.

REP_KAP Variabel dummy,1 jika perusahaan diaudit oleh KAP big-four dan 0 untuk selain itu.

e Ukuran error bagi perusahaan i, waktu $\mathrm{t}$

\section{HASIL PENELITIAN}

Statistik deskriptif variabel memberikan gambaran atau deskripsi mengenai 7 variabel yang menjadi data penelitian. Hasil pengolahan statistik deskriptif variabel ditunjukkan melalui tabel berikut: 
Tabel 2 Statistika Deskriptif

\begin{tabular}{lccccc}
\hline \multicolumn{1}{c}{ Variabel } & $\mathbf{N}$ & Minimal & Maksimal & Rerata & Deviasi Standar \\
\hline CAR & 180 & 0,0682 & 0,7574 & 0,2696 & 0,1349 \\
ROA & 180 & 0,0012 & 1,4760 & 0,1102 & 0,1399 \\
Size & 180 & 24,8504 & 32,3571 & 27,9208 & 1,5078 \\
KAP & 180 & 0 & 1 & 0,12 & 0,328 \\
ADTOR & 180 & 0 & 1 & 0,80 & 0,401 \\
OPINI & 180 & 0 & 1 & 0,64 & 0,480 \\
REP_KAP & 180 & 0 & 1 & 0,54 & 0,500 \\
\hline
\end{tabular}

Sumber: Pengolahan Data

Hasil uji hipotesis pada penelitian ini adalah sebagai berikut:

Tabel 3 Hasil uji Hipotesis

\begin{tabular}{lrrrrr}
\hline \multicolumn{1}{c}{ Variabel } & \multicolumn{1}{c}{ B } & \multicolumn{1}{c}{ T } & Sig. & VIF & Tol \\
\hline Konstanta & 0,612 & 2,981 & 0,003 & - & - \\
ROA & 0,159 & 2,196 & 0,029 & 0,925 & 1,082 \\
Size & $-0,011$ & $-1,537$ & 0,126 & 0,764 & 1,308 \\
KAP & 0,025 & 0,794 & 0,428 & 0,911 & 1,098 \\
ADTOR & $-0,003$ & $-0,138$ & 0,891 & 0,970 & 1,031 \\
OPINI & $-0,024$ & $-1,170$ & 0,243 & 0,958 & 1,044 \\
REP_KAP & $-0,051$ & $-2,253$ & 0,026 & 0,726 & 1,378 \\
\hline
\end{tabular}

$\mathrm{F}_{6,173}: 3,224$ sig. 0,005; Adj. $\mathrm{R}^{2}: 0,069$

Variabel Dependen: cumulative abnormal return

Sumber: Pengolahan Data

Berdasarkan hasil pengujian pada tabel 3 diketahui bahwa variabel Return on Asset memiliki nilai signifikan 0,029 yang lebih kecil dari alpha $(\alpha=0,05)$, maka dapat disimpulkan bahwa $\mathrm{H}_{1}$ diterima, Return on Asset berpengaruh terhadap Cumulative Abnormal Return. Return on asset merupakan salah satu rasio yang diperhatikan oleh investor untuk menilai kinerja perusahaan dalam memanfaatkan asset dalam kegiatan operasional yang ada untuk memperoleh income. Dengan hasil Return on asset yang bagus, maka return yang diharapkan oleh investor dapat semakin besar. 
Variabel ukuran perusahaan memiliki nilai signifikan 0,126 yang lebih besar dari alpha $(\alpha=0,05)$, maka dapat disimpulkan bahwa $\mathrm{H}_{2}$ tidak diterima, ukuran perusahaan tidak berpengaruh terhadap Cumulative Abnormal Return. Pengukuran total aset yang menjadi ukuran perusahaan, tidak akan berpengaruh terhadap return saham. Hal ini dikarenakan pada penelitian ini melihat selisih atau kelebihan return yang didapat investor dari return yang diharapkannya. Ukuran dan skala perusahaan yang tidak serta merta menjadi tolak investor untuk berinvestasi, besarnya return yang diperkirakan dan yang telah didapat menjadi tolak ukur utama, tanpa melihat ukuran perusahaan.

Variabel pergantian Kantor Akuntan Publik memiliki nilai signifikan 0,428 yang lebih besar dari alpha $(\alpha=0,05)$, maka dapat disimpulkan bahwa $\mathrm{H}_{3}$ tidak diterima, pergantian Kantor Akuntan Publik tidak berpengaruh terhadap Cumulative Abnormal Return. Kantor Akuntan Publik (KAP) adalah sebuah lembaga independen yang memberikan opini audit terhadap laporan keuangan perusahaan, sehingga laporan keuangan tersebut bebas dari salah saji yang material. Untuk menjaga independensi tersebut, maka perusahaan diwajibkan untuk mengganti Kantor Akuntan Publik sesuai dengan Peraturan Menteri Keuangan Nomor: 17/PMK.01/2008 dimana pembatasan masa pemberian jasa audit oleh KAP selama maksimal 5 tahun. Penggantian Kantor Akuntan Publik (KAP) dinilai wajar oleh investor dalam melakukan investasi, sehingga pergantian KAP tidak berpengaruh terhadap harga saham.

Variabel lama tugas pengauditan oleh auditor memiliki nilai signifikan 0,891 yang lebih besar dari alpha $(\alpha=0,05)$, maka dapat disimpulkan bahwa $\mathrm{H}_{4}$ tidak dapat diterima, lama tugas pengauditan oleh auditor tidak berpengaruh terhadap Cumulative Abnormal Return. Berdasarkan Peraturan Menteri Keuangan Nomor: 17/PMK.01/2008 tentang jasa akuntan publik mengenai pembatasan masa pemberian jasa audit oleh KAP selama maksimal 6 tahun berturut-turut dan auditor selama maksimal 3 tahun berturut-turut. Lama penugasan auditor dinilai wajar oleh investor dalam melakukan investasi, sehingga lama penugasan auditor tidak berpengaruh terhadap harga saham.

Variabel opini audit memiliki nilai signifikan 0,243 yang lebih besar dari alpha $(\alpha=0,05)$, maka dapat disimpulkan bahwa $\mathrm{H}_{5}$ tidak dapat diterima, opini audit tidak berpengaruh terhadap Cumulative Abnormal Return. Opini audit (Unqualified Opinion) akan diberikan oleh akuntan publik jika auditor telah melaksanakan pemeriksaaan sesuai dengan standar audit yang ditetapkan dalam SPAP dan telah mengumpulkan bahan-bahan pembuktian yang cukup untuk mendukung opini yang dinyatakannya tanpa adanya kesalahan saji yang material pada laporan keuangan. Laporan keuangan yang memiliki laporan laba negatif sekalipun tetap dapat diberikan opini wajar tanpa pengecualian selama bahan pembuktian benar untuk mendukung opini tersebut. Opini audit tidak serta merta menjadi alasan investor untuk melakukan investasi pada saham tersebut. 
Variabel Reputasi memiliki nilai signifikan 0,026 yang lebih kecil dari alpha $(\alpha=0,05)$, maka dapat disimpulkan bahwa $\mathrm{H}_{6}$ diterima, reputasi Kantor Akuntan Publik berpengaruh terhadap Cumulative Abnormal Return. Kantor Akuntan Publik big-four maupun non big-four memiliki penilaian tersendiri dari investor. Kantor Akuntan Publik big-four yang memiliki reputasi baik dapat menjadi acuan untuk menyakinkan investor dalam berinvestasi, oleh karena itu dapat terjadi pengaruh yang negatif terhadap harga saham.

\section{PENUTUP}

Berdasarkan hasil uji hipotesis, dapat diperoleh kesimpulan bahwa (1) Return on Asset memiliki pengaruh terhadap Cumulative Abnormal Return hasil penelitian ini konsisten dengan Ulupui (2005) serta didukung penelitian Syauta dan Widjaja (2009); (2) Ukuran perusahaan tidak memiliki pengaruh terhadap Cumulative Abnormal Return hal ini sesuai dengan penelitian sebelumnya dalam Diaz (2009), akan tetapi bertentangan dengan penelitian Maryanti (2009), Mulyani et al. (2009) dan Djam'an et al. (2010); (3) Pergantian Kantor Akuntan Publik tidak memiliki pengaruh terhadap Cumulative Abnormal Return hal ini sesuai dengan penelitian sebelumnya dalam Diaz (2009); (4) Lama penugasan auditor tidak memiliki pengaruh terhadap Cumulative Abnormal Return hal ini konsisten dengan penelitian sebelumnya dalam Diaz (2009); (5) Opini audit tidak memiliki pengaruh terhadap Cumulative Abnormal Return (CAR) hal ini konsisten dengan penelitian sebelumnya dalam Wicaksono dan Raharja (2012) dan Meiden (2008); (6) Reputasi KAP memiliki pengaruh terhadap Cumulative Abnormal Return (CAR) hal ini tidak sesuai dengan penelitian sebelumnya dalam Riyatno (2007).

Dalam penelitian ini, terdapat kelemahan dan keterbatasan penelitian yang mungkin akan mempengaruhi hasil penelitian sebagai berikut (1) sampel yang digunakan dalam penelitian ini terbatas hanya pada perusahaan manufaktur yang terdaftar di Bursa Efek Indonesia, (2) penelitian ini belum memasukkan variabel-variabel lain yang dapat mempengaruhi Cumulative Abnormal Return, (3) periode penelitian yang digunakan hanya terbatas tiga tahun. Periode waktu yang terbatas tersebut tentunya mempengaruhi hasil penelitian ini.

Rekomendasi yang dapat diberikan penulis untuk penelitian selanjutnya adalah sebagai berikut (1) penelitian selanjutnya mungkin dapat mempertimbangkan untuk menggunakan objek penelitian seluruh perusahaan yang terdaftar di BEI, (2) penambahan variabel-variabel lain yang menjadi faktor pengaruh terhadap Cumulative Abnormal Return, terutama dari sisi pandang 
fundamental rasio keuangan lainnya, (3) penelitian selanjutnya sebaiknya menggunakan rentang waktu yang lebih lama agar mendapatkan sampel yang lebih banyak seperti 5 tahun.

\section{REFERENSI:}

Djam'an, Nurhidayah., Gagaring Pagalung, Tawakkal. 2010. Pengaruh informasi Laporan Arus Kas, Laba dan Size Perusahaan Terhadap Abnormal Return Saham Pada Perusahaan Manufaktur yang Terdaftar di Bursa Efek Indonesia.

Diaz, Marsela. 2009. Analisis Reaksi Pasar Terhadap Pengumuman Pergantian Kantor Akuntan Publik (Studi Pada Perusahaan Publik Di Indonesia). Pontianak: Universitas Brawijaya.

Fanny, Margaretta dan Saputra, S. 2005. Opini Audit Going Concern : Kajian Berdasarkan Model Prediksi Kebangkrutan, Pertumbuhan Perusahaan, Dan Reputasi Kantor Akuntan Publik, (Studi Pada Emiten Bursa Efek Jakarta). Prosiding Simposium Nasional Akuntansi VIII, hlm. 966-978.

Ghozali, Imam. 2006. Aplikasi Analisis Multivariate dengan Program SPSS. Semarang: Badan Penerbit Universitas Diponegoro.

Gitman, Lawrence J. 2008. Principles of Managerial Finance. $12^{\text {th }}$ Edition. Addison Wesley.

Hartono, Jogiyanto. 2008. Teori Portofolio dan Analisis Investasi. Edisi Kelima. Cetakan Pertama. Yogyakarta: BPFE.

Kawijaya, Nelly., Juniarti. 2002. Faktor-Faktor yang Mendorong Perpindahan Auditor (Audit Switch) Pada Perusahaan-Perusahaan di Surabaya dan Siduarjo. Universitas Kristen Petra.

Kurniawati, Indah. 2006. Analisis Pengaruh Pengumuman Earning Terhadap Abnormal Return dan Tingkat Likuiditas Saham: Analisis Empiris pada Nonsynchronous Trading. Yogyakarta: Universitas Ahmad Dahlan.

Meiden, Carmel. 2008. Pemgaruh Opini Audit Terhadap Return dan Volume Perdagangan Saham. Institut Bisnis dan Informatika Indonesia.

Mulyani, Sri., Nur Fadjrih Asyik, Andayani. 2007. Faktor-Faktor yang Mempengaruhi Earning Response Coeficient pada Perusahaan yang Terdaftar di Bursa Efek Jakarta. STIESIA Surabaya.

Myers, Stewart C. 1989. Signaling and Accounting Information. NBER Working Paper Series.

Paptitorini, Januarti. 2007 . Analisis Pengaruh Kualitas Audit, Debt Default dan Opinion Shoping Terhadap Penerimaan Opini Going Concern. Prosiding Simposium Nasional Akuntansi X.

Scott, William R. 2003. Financial Accounting Theory. Third Edition. Toronto: Prentice Hall. Syauta, Risky Christian., Indra Widjaja. 2009. Analisis Pengaruh Rasio ROA, LDR, NIM, dan NPL Terhadap Abnormal Return Saha Perbankan di Indonesia Pada Periode Sekitar Pengumuman Subprime Mortgage. Journal of Applied Finance and Accounting Vol. 1 No.2 June, hlm. 351 - 367.

Ulupui, I G. K. A. 2009. Analisis Pengaruh Rasio Likuiditas, Leverage, Aktivitas, dan Profitabilitas Terhadap Return Saham. (Studi Pada Perusahaan Makanan dan Minuman Dengan Kategori Industri Barang Konsumsi di BEJ). Universitas Udayana.

Wicaksono, Arie., 2012. Adakah Kandungan Informasi Laporan Audit WTP dengan Paragraf Penjelas dan Laporan Audit WDP?. Jurnal Dinamika Akuntansi Vol. 4, No. 1, Maret, hlm. 47-55. 